\title{
Bajo's Philosophical Interpretation Toward The Cruising Accuracy Of Cultural Studies Throught The Role Of Language
}

\author{
Lilik Rita Lindayani ${ }^{1}$, Fina Amalia Masri ${ }^{2 *}$ \\ Language and Literature Department, FIB, Universitas Halu Oleo, Kendari ${ }^{1,2}$ \\ \{finaamaliamasri@gmail.com ${ }^{2}$ \}
}

\begin{abstract}
This research article aimed to find out the Bajo's philosophical interpretation toward the cruising accuracy of cultural studies through the role of language. This research used qualitative research methods through an interpretive and constructive paradigm that viewed social reality as an interactive relationship (reciprocal). The analysis was carried out by perspective. So that it depended on the quality of observation and meaning, to reveal something behind the reciprocal phenomena of language in the life of the Bajo ethnic (especially Bajo ethnic in Katela Island) and its rituals. This research found that there are two reciprocal roles of language that are interpreted philosophically through the cruising of cultural studies, namely the role of instrumental and the role of material._In its role as an instrument, language can be in the form of linguistic phenomena that support individual behavior characterized by the emergence of understanding in interaction.The data shows, that linguistic reference can reveal the potential for infrastructure that builds the identity and ideology of ethnic Bajo Linguistic, in its position as a scientific discipline, plays an important role in creating a new grammatical context in determining language as an instrument of identification for a community, because there is no communicative movement of linguistic logic if language is not born as a marker. Meanwhile as the material role, language is tied to sign and symbols in which its convention of meaning laid on the function. Reciprocally it is assumed that the geographic location of Katela Island supports the theological and teleological ideas of the Bajo people who inhabit it.
\end{abstract}

Keywords: philosophical interpretation; cultural studies; role of language; Bajo

\section{Introduction}

Etymologically, communication comes from the Latin word communication and comes from the word communist which means 'the same', the meaning is it is same in meaning (Hidayat, 2014: 26). Language as a capital of social interaction that involves many people and in it, a convention is manifested regarding the meaning of language itself. When language development is placed back in a social context (linguistics turn), in this case language is part of social capital which refers to a system that has an impact and has a meaningful impact. The arbitrary nature of language allows for reciprocity between language and culturist of local 
wisdom which offers a simple concept in a symmetrical exchange for enrichment of vocabulary and culture, in which each party places it in a position and role according to its potential.

Viewed from a linguistic perspective, the level of human thinking about language does not just make it as an identity. Language is increasingly of economic value from its social and cultural context. Culture is clearly related to humans, both as individual and social beings. If language is categorized as capital, then in line with the economic principle of capital, it must always be developed to obtain maximum benefits. Competitively, the advantages referred to in this case are symbolic gains or public recognition.

Cultural issues related to the transition of life of the Bajo people from land to sea settlement patterns, based on previous research, give rise to uncertain statements. One side states that the Bajo people have their own culture, stated in the statement Bahtiar (2011: 51), that:

In their life as sea nomads, the Bajo tribe has its own culture that is different from the culture of other communities, which is called the culture of the Bajo tribe. Bajo ethnic culture is used by the Bajo community to deal with the environment as well as a pattern of interaction within their ethnic groups and as a reference for identity in interactions with other ethnic groups. Based on cultural classifications, one of which is ethnic culture, the Bajo culture contains rules and values that are embodied in the symbols of expression that exist in the various social institutions of the Bajo community. "

However, on the other hand, there is a statement that the ancestors of the Bajo people left Ussu with a Bugis cultural background and made changes according to the conditions they experienced in the language of that time, including the emergence of a language that became a symbol of fellow Bajo people called boang sama (see Liliweri, 2014: 461).

Razanov (2016) wrote an article entitled "Language and Identity Explored" in the Journal of Art and Humanities, USA. In this article, Razanov describes the broad relationship between language and identity that can be discussed in applied linguistics, sociology, communication, and other scientific fields. According to him, the unique historical context makes it possible to test this relationship. Therefore, through the concept put forward by Razanov, the researcher was inspired to explore the data in this study through the work of Historical Comparative Linguistics. This was done to trace the origin of the Bajo ethnic language on Katela Island to then determine the space for this ethnic identity to move.

Basri (2017), in his scientific journal entitled Phylosophical View and Rarambangah System: A Local Genius of the Bajau People Living at Bungin Permai Village, Southeast Sulawesi. Discusses the philosophical views of the Bajau (Bajo) people along with the values inherited from their ancestors, which are preserved in socio-cultural beliefs and are still considered to be the supernatural powers of this ethnic group. Things as stated, are still always mentioned when they conceptualize and express the essence of life, purpose, orientation, knowledge and interpretation of cosmology, this is a local form of genius that allows them to survive and thrive in a sea full of challenges.

In this research, the role of the scientific field of linguistics is represented to oversee the performance of Cultural Studies, both totally and partially. The consideration is that several humanities cases have led to the strengthening of a positivistic view of the work of cultural studies which is deconstructive and can no longer be isolated. This is related to the relative truth of a science in cultural work because a cultured system is not automatically dismantled without looking at ethical elements, both from certain scientific disciplines and multidisciplinary. 
To find out the Bajo's philosophical interpretation toward the cruising accuracy of cultural studies through the role of language, the language expression of the Bajo people in this study is directed at all behavior of social life including the behavior of interacting with the environment and the rituals of the Bajo ethnic community on Katela Island. Layout of universal linguistic patterns that indicate the relationship between cultural social systems, environment, and evolution in the parts of system relationships. Macro linguistics review in this case allows the owner and speakers to play a role because normatively there is a choice in language. The influence of the thought of the famous philosopher, Wittgenstein II, can be seen especially his thoughts on language matters, particularly language in daily life practices or the function of language in social life. Bourdieu (Harker et. al (ed.), 1990: 203) believes that language is a way of life of a social group that essentially provides services for the achievement of practical goals. If language is the capital, language requires a language market and social space. Symbolic benefits can turn into material benefits when accompanied by simultaneous intellectual, cultural and social competences.

\section{Methods}

As a method known to be naturalistic, qualitative research methods in post positivism philosophy are often referred to as interpretive and constructive paradigms, which view social reality as an interactive symptom relationship (reciprocal). This research further explains and interprets reciprocation in the ethnic Bajo rituals that inhabit Katela Island by seeing the construction of objects as they are (natural setting), not manipulated by the researcher and the presence of the researcher does not affect the dynamics of the object.

Starting from the idea that there is no single point of view in a study, all data is viewed holistically. Perspective analysis is used as a scalpel. Accompanying Nietzsche's thought for a strategy he called "genealogy" in historicism, in order to observe the traditional creativities that exist in society, Nietzsche believes that every creation has a special set of interests for a particular location or context (Levine, 1976: 88-101). Thus, this study relies heavily on the quality of observations and meaning to reveal something behind the phenomenon. As stated, when aligned with the control of phenomena by Strauss (2009: 5), the phenomena in question may be collaborated with the researchers' ideas and field facts, namely the reciprocal phenomena of linguistics in the life of the Bajo ethnic group along with its rituals. The quality of the data is extracted empirically without simulation so that it has theoretical consequences for the achievement of research objectives.

\section{Result and Discussion}

\subsection{The Role of Linguistic Reciprocal}

\section{a. Instrumental Role}

In the sub-background, several things have been mentioned about the position of the term reciprocation of language in this study. In line with that, it can be emphasized that the essence of language is a term that arises due to the polarity of language in collaboration with a series of events that mark other events. 
The potential and opportunities to create a new culture can be realized in a language system or it can also be interpreted as a sign of linguistics. Language signs are always in correspondence with their markers. The perspective of the common people, in this case the Bajo ethnic group, often thinks that the similarity of vocabulary in communication shows a sign of kinship line which they call "sama". This allows for arbitrary diction of reality. The theory of linguistics relativity states that each culture will interpret the world in a different way and that the differences will be coded in language (this is in line with Saussure's view that we share reality arbitrarily) (Thomas and Shan Wareing, 2007 : 37). The embryo of related languages or only a combination of lexical sequences due to the influence of cultural assimilation because these two tribes in the view of the people of Sulawesi are well known for their expansion patterns of colonies or nomads. The difference is that the Bajo tribe expanded at sea, while the Bugis on land.

The word linguistic does not merely refer to grammatical cases that are learned through linguistic interactions, such as the description of a particular language that falls into the micro linguistics realm called by Ferdinand de Saussure as "La Langue" which means a descriptive system of the intrinsic elements of language building blocks on the language itself (sounds, words, phrases, and sentences). The linguists compile these descriptions to explain this utterance de Saussure calls "La Parole", while at the macro linguistic level it includes general language structuring in collaboration with other sub-disciplines. Delaeuze and Felix Guattari (in Rhizome, 1976; Lubis, 2014: 68), further explore language management, namely:

"There is no language in the language itself, nor is there universality in language, language is a collection of dialects, utterances, popular expressions (slang) and specific languages. There is no ideal spokesperson in communication, except for the homogeneous linguist community. There is no mother tongue, except for the usurping of power by the dominant discourse in a political diversity".

Seeing such a relationship, the accuracy of exploring Cultural Studies through the role of language has led to many philosophical interpretations. At one point, the perspective between agency and structure grapples with what Bourdieu calls constructivist structuralism. With structuralism or structural, humans are dealing with objective structures and are independent of human consciousness itself and have the power to shape actions (Arif, 2010: 197).

Linguistics, in its position as a scientific discipline, plays an important role in creating a new grammatical context in determining language as an instrument of identification for a community, because there is no communicative movement of linguistic logic if language is not born as a marker. The linguistic aspect of linguistic signs is a form of engineering of speech to see the existence of language itself so as to give birth to a structural format that can be studied and evaluated further synchronously and diachronic. Language can be a visual medium in some cases a semiotic act. The visual media referred to here are linguistic phenomena that support individual behavior which is thought to lead to understanding in interactions. Cassirer (in Taufiq, 2016: iii) Reveals that humans live in a symbolic universe. Language, myth, art and religion are parts of the universe. They are the threads that form the symbolic web, the tangled web of human experience. In this case, it is returned to the nature of human existence and language as a characteristic of human playing with other creatures. Wardhaugh (1972: 3) said "Language is a system of arbitrary symbols used for human communication. Meanwhile, De Vito (1970: 7), reveals “....Language is a potentially selfreflexive, structured sytem of symbols which catalog the objects, events, and relations in the world" The nature of reflexivity explains the fact that humans can use language to think and talk about language itself. Yule (2015) call it a unique feature of human language, which is a feature where humans can explain and think about language from the point of use until it 
arrives at an ideological point. Language here is not merely a language factor as a set of grammatical constructs in the context of theoretical ethics, but on this occasion, language is also a major cultural issue and also core instrument for cultural studies.

\section{b. Material Role}

Layout of universal linguistic patterns that indicate the relationship between the cultural social system, environment, and evolution in the parts of system relationship. Macro linguistic review in this case allows the owner and speakers to play a role because normatively there is a choice in language.

Linguistics is tied to symbols and symbols, even though these signs and symbols do not determine between the sound of the language and the designation they produce. The sound of language as a name is only an identity for something that is marked. For example, the word meja does not always refer to a square object with four legs made of wood, because in fact the design of a table can change, as well as the material of the table. The convention's meaning lies only in its function. In a different language "meja" changed the naming, for example in English to be table, in German to be tabelle, etc. The arbitrary of the language is actually caused different naming variations in each language. The conditions as referred to, are generally not a questionable case. Problems arise after a particular community wants a group identity. For example, ethnic or national identity. When geographic location cannot interfere, then language plays a role.

The Bajo people or the Bajo ethnicity on Katela Island, it was claimed in several previous studies to have a kinship with the Bugis tribe in South Sulawesi, so that the potential for kinship is considered to have contributed to the linguistic behavior of this ethnic ritual behavior. If the geographic constellation of the dimensions of movement space for the Bajo ethnic group on Katela Island, it can be seen that this ethnic group inhabits the island which is bordered by the Tiworo Strait with one mainland, namely Lasama Village, which is mostly inhabited by the Muna ethnic group who is one of the indigenous tribes in the region.

Judging from the regional boundary data, language sensitivity is usually tied to the environment and geographical position, as well as the Bajo ethnic group on Katela Island, they can interact using the local language (Muna language), although passively. Reciprocally it is assumed that the geographic location of Katela Island supports the theological and teleological ideas of the people who inhabit the island as well as its culture. In line with that, the data in the field presents the recognition of the Bajo ethnicity on the island as a representation of the Bugis tribe from the South of Sulawesi Island. Based on field observations, Bajo people everywhere who inhabit the waters of Southeast Sulawesi, including ethnic Bajo who live on Katela Island, West Muna Regency, when they meet someone who is Buginese, they will say "we are the same" meaning "we are related". The representation of the Bugis in the existence of the Bajo ethnicity was developed based on the Sawerigading mythology about the origin of the Bajo people who entered the waters of the Sulawesi Strait as stated by Suyuti (1996) and Liliweri (2014).

Cultural issues related to the transition of life of the Bajo people from land to sea settlement patterns, based on previous research, give rise to uncertain statements. One side states that the Bajo people have their own culture, stated in the statement Bahtiar (2011: 51), that:

"... In their life as sea nomads, the Bajo tribe has its own culture that is different from the culture of other communities, which is called the culture of the Bajo tribe. Bajo ethnic culture is used by the Bajo community to deal with the environment as well as a pattern of interaction within their ethnic groups and as a reference for identity in interactions with other ethnic groups. Based on cultural classifications, one of which is ethnic culture, the 
Bajo culture contains rules and values that are embodied in the symbols of expression that exist in the various social institutions of the Bajo community. "

However, on the other hand, there is a statement that the ancestors of the Bajo people left Ussu with a Bugis cultural background and made changes according to the conditions they experienced in the language of that time, including the emergence of a language that became a symbol of fellow Bajo people called boang sama (see Liliweri, 2014: 461).

Starting from the above thoughts and observations on the concept of the uniqueness of the Bajo people on Katela Island, there are interesting things related to language, apart from the ethnic presence as a representation of the Bugis people, the Bugis language also plays a role in several daily activities and certain moments that are carried out. Ethnicity in fact, one of the most respected sanro in the area turned out to be not a native Bajo tribe, but a Buginese who was fluent in Bajo language and had regenerated inhabiting the island. The nature of the Bajo people who are shy and introvert but have great respect for the presence of other tribes, especially the Bugis who are considered part of them are presumably presenting a language game in this ethnic life.

In the theory of Cultural Materialism "one consipicuous omission", namely regarding a glaring negligence when forgetting the role of language in the process of legitimizing a culture, then Harris (1980) places language as an instrument to see fundamental ethics and behavior that synergizes to build infrastructure, structure, and superstructure and characteristics of a group of people. This, as stated by Harris, implies the dominant role of language in studying cultural materials for the study of the culture of certain community groups because language at the cultural level is not an alternative instrument. Language describes all levels.

\section{Conclusion}

Based on the results and discussion, the Bajo's philosophical interpretation toward the cruising of cultural studies is not neglected the role of language shows that linguistics, in its position as a scientific discipline, plays an important role in creating a new grammatical context in determining language as an identification instrument for a community. The role of the scientific field of linguistics is represented to oversee the performance of Cultural Studies, both totally and partially. The philosophical view of the Bajo people about who knows their language is a close relative "sama", showing that language is the strongest way of this ethnic to be able to adapt to the ethnics on the mainland. In this study, the power of language presents as a language game in this ethnic life, where language becomes ethics and fundamental behavior that work together to build infrastructure and social characteristics of the Bajo community.

\section{References}

[1] Alwasilah, A. Chaedar, 1992. Beberapa Madhab dan Dikotomi Teori Linguistik. Bandung: Angkasa.

[2] Arif, Syaiful, 2010. Refilosofi Kebudayaan: Pasca Struktural. Yogyakarta: Ar-Ruzz Media.

[3] Bahtiar, 2011. Transisi Kebudayaan Suku Bajo. Kendari: HISPISI Cabang Sultra. 
[4] Basri, La Ode Ali. 2017. "Phylosophical View and Rarambangah System: A Local Genius of the Bajau People Living at Bungin Permai Village, Southeast Sulawesi". Mudra Journal of ISI Denpasar. Vol. 26 No. 3, pages: 1-11. repo.isi-dps.ac.id

[5] Devito, Joseph A. 1988. The Psychology of Speech and Language An Introduction to Phycholinguistics. New York: Random House Inc.

[6] Harker, Richard, Cheelen Mahar, dan Chris Wilkes (ed.).2009. (Habitus x Modal) + Ranah $=$ Praktik. Yogyakarta: Jalasutra.

[7] Levine, Peter. 1976. Nietzsche and the Modern Crisis of The Humanities. New York: Harper \& Row Publisher.

[8] Liliweri, Alo. 2014. Pengantar Studi Kebudayaan. Bandung: Nusa Media.

[9] Lubis, Akhyar Yusuf. 2015. Pemikiran Kritis Kontemporer. Jakarta: Raja Grafindo Persada.

[10] Strauss, Anselm dan Juliet Corbin 2009. Dasar-Dasar Penelitian Kualitatif. Yogyakarta: Pustaka Pelajar.

[11] Razanov, Thomas. 2016. Language and Identity Explored. Journal of Art and Humanities. Vol. 5. No. 6. 2016. https://www.theartsjournal.org

[12] Suyuti, Nasruddin. 2011. Orang Bajo di Tengah Perubahan. Ombak: Yogyakarta.

[13] Thomas, Linda dan Shan Wareing. 2007. Bahasa, Masyarakat dan Kekuasaan. Yogyakarta: Pustaka Pelajar.

[14] Wardhaugh, Ronald. 1972. Introduction to Linguistics. New York: Mc Graw-Hill Inc. 